\title{
Amylase from bacillus thuringiensis isolated from tapioca waste: isolation, partial purification and characterization
}

\author{
Zusfahair $^{1}$, Dian Riana Ningsih ${ }^{1}$, Dwi Kartika ${ }^{1}$, Amin Fatoni $^{1,2^{*}}$ \\ ${ }^{1}$ Department of Chemistry, Faculty of Mathematics and Natural Sciences, Universitas Jenderal Soedirman, Purwokerto 53123, Indonesia. \\ ${ }^{2}$ Center for Maritime Biosciences Studies, Universitas Jenderal Soedirman, Purwokerto, Jawa Tengah 53123, Indonesia. \\ *Corresponding Author: aminfatoni@unsoed.ac.id
}

\section{Article history :}

Received 6 Feb 2016

Accepted 22 Feb 2016

\section{GRAPHICAL ABSTRACT}

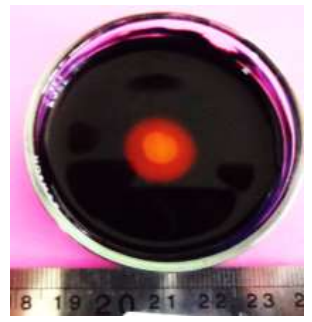

\begin{abstract}
Microorganism enzymes are the most widely used in industrial applications. Tapioca liquid waste could be a great source of amylase for producing bacteria. The aim of this research was to isolate the amylase that is producing bacteria form the tapioca waste, to produce amylase and to purify the resulted amylase. The screening, identification, and the optimal production condition of the amylase for producing bacteria were studied. The optimization of bacteria production growth phase and the amylase production time were investigated. The crude amylase was purified using ammonium sulfate fractionation followed by SDS PAGE electrophoresis to identify the molecular weight and the purity of the amylase. The amylase activity assay was based on the measuring of resulted reducing sugar by Somogyi-Nelson method. The result showed that the amylase producing bacteria was identified as Bacillus thuringiensis. The exponential phase of the bacteria growth for bacteria adaptation before production was $18 \mathrm{~h}$ and the optimal production time of amylase enzyme was $24 \mathrm{~h}$. The highest specific activity of the purified amylase was fraction (FHD) $40 \%$ with specific activity of $37.56 \pm 0.38 \mathrm{U} / \mathrm{mg}$. The SDS PAGE of FHD $40 \%$ profile showed two clear bands with molecular weight of $32 \mathrm{kDa}$ and 35 $\mathrm{kDa}$ respectively.
\end{abstract}

Keywords: tapioca liquid waste, Bacillus thuringiensis, amylase, isolation, purification

(c) 2016 Penerbit UTM Press. All rights reserved http://dx.doi.org/10.11113/mjfas.v12n1.404

\section{INTRODUCTION}

Amylase is an industrially important enzyme that degrades starch to a simple sugar. Amylase has emerged as one of the leading biocatalyst with proven potential to be use in a wide array of industrial applications, such as additives in processed food industries, additives in detergents, wastewater treatment, bio pulping, bioremediations and molecular biology. Amylases as starch hydrolytic enzymes have a great consumption of about 30 $\%$ of the world's enzyme application [1].

Generally, enzymes can be produced from plants, animals and microorganisms [2]. The advantages of using microorganism as enzyme sources stimulate wide exploration of extracellular enzymes in several strains and microorganism sources. Enzymes from bacteria and fungi are the dominant enzyme that is used in industrial applications [3]. Previous studies on the exploration and isolation of enzymes from local Indonesian microorganism have been reported, for example thermophilic amylase from hot spring $[4,5]$ that resulted thermostable enzymes. Other interesting enzyme-producing bacteria sources source domestic and industrial waste, since they are rich of nutrients for substrate-degrading bacterial, thus, high productivity in the substrate-degrading enzymes. Various wastes origin bacteria have been reported such as lipase for producing bacteria from landfill [6], oil processing plant waste [7]; protease-producing bacteria from tofu waste [8], marine waste [9] and amylase-producing bacteria from municipal solid waste $[10,11]$.

Tapioca liquid waste is a good environment for amylase-producing bacteria, thus, could be a potential source for amylase production. This study explored the amylase-producing bacteria from local tapioca liquid waste as amylase sources. The bacteria isolates were screened qualitatively and the best bacteria isolate was selected to produce a high activity of amylase. The highest amylase was then produced and characterized for further applications.

\subsection{EXPERIMENTS}

\subsection{Materials and Instruments}

The used materials in this study were tapioca liquid waste (Cipawon, Bukateja, District of Purbalingga), nutrient broth, nutrient agar, starch agar, glucose, $\mathrm{Cu}-$ 
tartrate alkalis, arsenomolybdate, sodium chloride, sodium tungstate, sulfuric acid, polyacrylamide, tris-buffer, SDS (sodium dodecyl sulfate), TEMED ((N,N,N',N'tetramethylethylenediamine), APS (ammonium persulfate), glycine, DTT (dithiothreitol), mercapto ethanol, bromophenol blue, glycerin, methanol, and coomasie blue, marker kit (Bio-Rad) and ammonium sulfate.

The main equipments used are autoclave (SMIC), shaker (Kotterman 4010), incubator (Memmert), analytical balance (Ohause), hot-plate stirrer (Rommetsbacher) centrifuge (Haraeussepatech) and Spectrophotometer UV Visible (UV Shimadzu 1800)

\subsection{Bacteria Screening}

Seven isolates that showed amylase activity in the previous preliminary study [12], were incubated in a starch broth medium for $48 \mathrm{~h}$ at room temperature using a shaker incubator. The resulted growth isolates were centrifuged (7000 rpm, $4{ }^{0} \mathrm{C}, 15 \mathrm{~min}$ ) to separate the extracellular amylase from the bacterial cells. Then, the supernatants and crude extract of amylase were then determined for their amylase activities. The genus and species of isolates with the highest amylase activity were identified, and then were used for the next procedures.

\subsection{Amylase activity assay}

The amylase activity assay was based on the reducing sugar released in the hydrolysis of starch by the enzyme. Five $\mathrm{ml}$ of $1 \%(\mathrm{~b} / \mathrm{v})$ starch was pre-incubated for 5 $\min$ at $35^{\circ} \mathrm{C}$. One $\mathrm{mL}$ solution of amylase and $0.5 \mathrm{~mL}$ of $0.85 \%$ sodium chloride were added, and the incubation was continued for $30 \mathrm{~min}$. The enzyme activity was then deactivated by adding $0.5 \mathrm{ml}$ of $10 \%$ sodium tungstate and $1.5 \mathrm{ml}$ of $0.7 \%\left(\mathrm{NH}_{4}\right)_{2} \mathrm{SO}_{4}$. A control tube was also prepared using the same procedure in the absence of amylase. The sample and control solution were filtered and the reducing sugar was measured. The reducing sugar was then measured according to the Somogyi- Nelson method [13] by preparing a series of $5 \mathrm{ml}$ test tube contained $0.2 \mathrm{ml}$ of sample with control and standard solution of glucose of $70,90,110,130$, and $150 \mathrm{mgml}^{-1}$ respectively. Alkaline cupric tartrate of $0.2 \mathrm{ml}$ was then added in each tube and heated at $100^{\circ} \mathrm{C}$ for $30 \mathrm{~min}$. This mixture was then cooled and added with $0.2 \mathrm{ml}$ of arsenomolybdate followed by 7.4 $\mathrm{ml}$ of distilled water. The absorbance of the samples was measured at $750 \mathrm{~nm}$.

\subsection{Bacterium identification using 16S rRNA Amylase activity assay}

Molecular identification of protease producer bacterium was determined with partial genetic identification of $16 \mathrm{~S}$ ribosomal RNA. Bacterium was cultured on NA medium for 72 hours. DNA was extracted using GES method [14]. Primers of 9F (5'AGRGTTTGATCMTGGCTCAG-3') and 1492R (5'-
ACGGYTACCTTGTTAYGACTT-3') were used in PCR amplification using PEG precipitation method [15]. The result then was purified using ethanol purification, and base sequencing was read using automated DNA sequencer (ABI PRISM 3130 Genetic Analyzer, Applied Biosystems). The obtained data were trimmed using MEGA 4 software, assembled with BioEdit, and converted to FASTA format. The FASTA DNA was confirmed with BLAST for DNA homolog online at DNA database homepage such as DDBJ (http://www.ddbj.nig.ac.jp) or NCBI (http://www.ncbi.nlm.nlh.gov/). Finally, the phylogenetic three and family of the bacterium were analyzed using Clustal X and NJ plot software.

\subsection{Determination of the optimal condition for amylase production.}

Bacteria were grown at room temperature and the cell density was measured by observing the optical density (OD) at $600 \mathrm{~nm}$ every $3 \mathrm{~h}$ for $48 \mathrm{~h}$. The growth phase of the bacteria was then observed, and the exponential phase was used to produce amylase. The exponential phase of the bacteria was then grown for enzyme production by incubating at room temperature in a shaker incubator for 48 h. Every $6 \mathrm{~h}$, crude amylase was tested for their amylase activity. The optimum production time was determined by selecting the highest amylase activity together with the lowest production time.

\subsection{Determination the optimum $\mathrm{pH}$ and temperature of amylase}

The optimum operational condition including $\mathrm{pH}$ and temperature of crude amylase were determined. The $\mathrm{pH}$ effect was studied according to the amylase activity assay with various buffer $\mathrm{pH}$ of 2.0 to 7.0. The temperature effect on the amylase activity was performed at the optimum $\mathrm{pH}$ in the various incubation temperature ranging from 30 to $45{ }^{0} \mathrm{C}$.

\subsection{Amylase fractionation}

Crude amylase was partial purified by ammonium sulfate fractionation. The fractionation was performed by gradually adding ammonium sulfate in a series concentration of $20 \%, 40 \%$ and $60 \%$ (w / v), respectively. The mixture was then centrifuged at $7,000 \mathrm{x} \mathrm{g}$ for 10 minutes. All of the fractions were collected. Then, they were then dialyzed by using cellophane dialysis membrane. The enzyme activity, protein content and specific activity were analyzed. The molecular weight of enzyme fraction with the highest specific activity was determined using SDS PAGE electrophoresis.

\subsection{Amylase determination using SDS PAGE}

The Sodium Dodecyl Sulfate polyacrylamide gel electrophoresis (SDS-PAGE) was used to identify the 
amylase purity and molecular weight. SDS-PAGE electrophoresis used a discontinue gel system consisting of stacking gel and separating gel. A sample of $100 \mu \mathrm{l}$ was added with $25 \mu \mathrm{l}$ sample buffer, boiled for 2 minutes, kept in ice for 15-30 min, and then injected into the well. Electrophoresis was carried-out at $20 \mathrm{~mA}$ and $100 \mathrm{~V}$. Electrophoresis was stopped when the dye samples reached the limit of 0.3 to $0.5 \mathrm{~cm}$ at the bottom of the gel. Gel was soaked in the brilliant blue coomasie dye, agitated gently for $2 \mathrm{~h}$, and then washed by soaking in a de-staining solution. Molecular marker kit (Bio-Rad) was used for the reference of protein molecular weight.

\subsection{Protein assay}

Protein concentration of the purified enzyme was determined by Lowry's method of protein estimation [16]. The absorbance at $660 \mathrm{~nm}$ was recorded after the reaction and compared with the standard graph plotted reacting a standard protein (BSA).

\section{RESULTS AND DISCUSSION}

The research was started with sample collection from the tapioca liquid waste. The locations of sample collection were "mixing unit", "control unit" and "final unit" of waste treatment. The bacteria isolation found seven isolates that showed clear zone, produced amylase, in a starch agar medium (Fig. 1). Iodine solution was used to stain the remaining starch. It gave result of a clear zone in the hydrolyzed starch by the bacterial amylase. The isolates showed amylase activity in the qualitative screening were then extracted as the crude amylase and tested for the amylase activity. The bacteria showed highest amylase activity that was coded as HCB6 (Fig. 2). Then, the HCB6 bacteria were then used for further study.

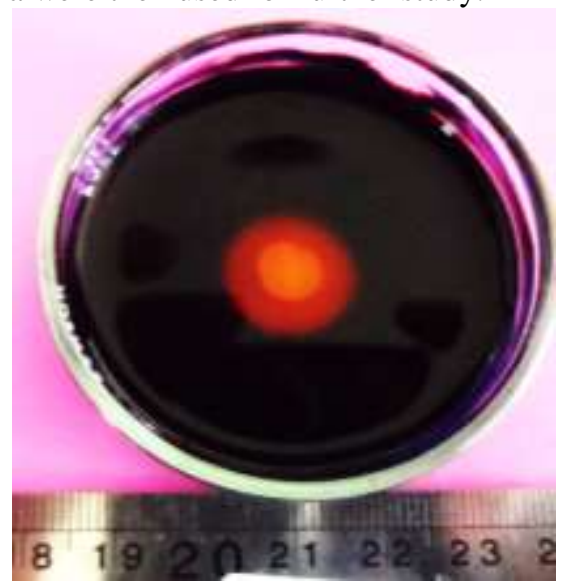

Fig. 1 Amylase- producing bacteria colony showed a clear zone in the starch medium agar.

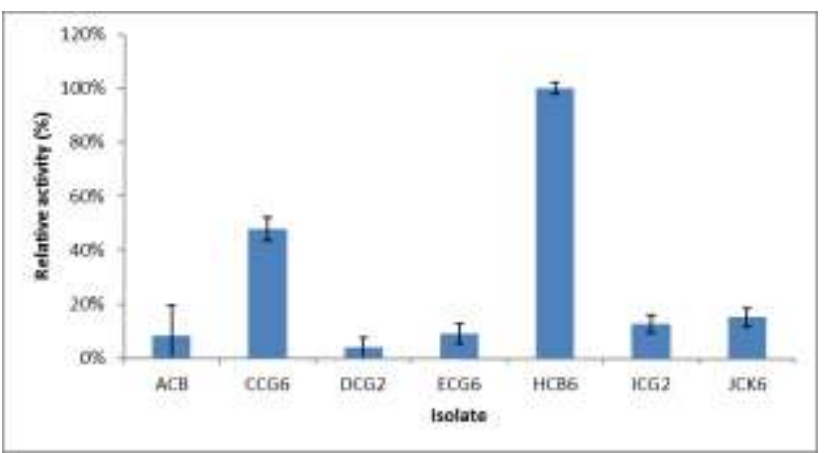

Fig. 2 Amylase relative activity of various amylase-producing bacteria was isolated from tapioca waste.

The bacteria showed the highest amylase activity was then identified using 16S rRNA analysis. The primers used were $9 \mathrm{~F}$ and $1492 \mathrm{R}$, and the sequencing analysis was performed in the First Base Malaysia. The result showed that the HCB6 was Bacillus (Fig. 3), and the position of the strain of HCB6 in the phylogenetic tree was tracked. A number of sequences representative some Bacillus sp were selected from Gen bank database. The phylogenetic tree indicated that strain HCB6 and Bacillus thuringiensis were identic (99\%). Therefore, the strain HCB6 was proposed as Bacillus thuringiensis and coded as Bacillus thuringiensis HCB6. Previous studies reported that the amylase for producing bacteria of Bacillus sp. could be identified and based on 16S rRNA gene sequencing and phylogenetic analysis [17].

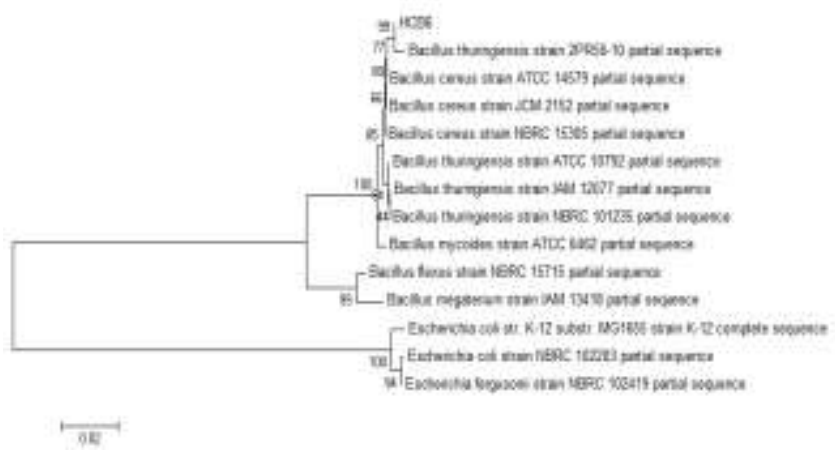

Fig.3 Bacteria phylogeneic tree resulted in the 16S rRNA analysis showed the amylase-producing bacteria was Bacillus thuringiensis.

The phases of bacteria growth were observed by measuring the turbidity of the bacteria in the broth medium (Optical Density) by measuring it at $600 \mathrm{~nm}$. Determination of growth curve was performed to find out the optimum time start of the bacteria in the amylase production, which was in the exponential phase where the cells perform active growth. This would shorten the adaptation phase when bacteria were in the amylase production. The growth phase showed an initiated (adaptation) phase in incubation time of 0 to $12 \mathrm{~h}$. The bacteria continued into exponential phase 


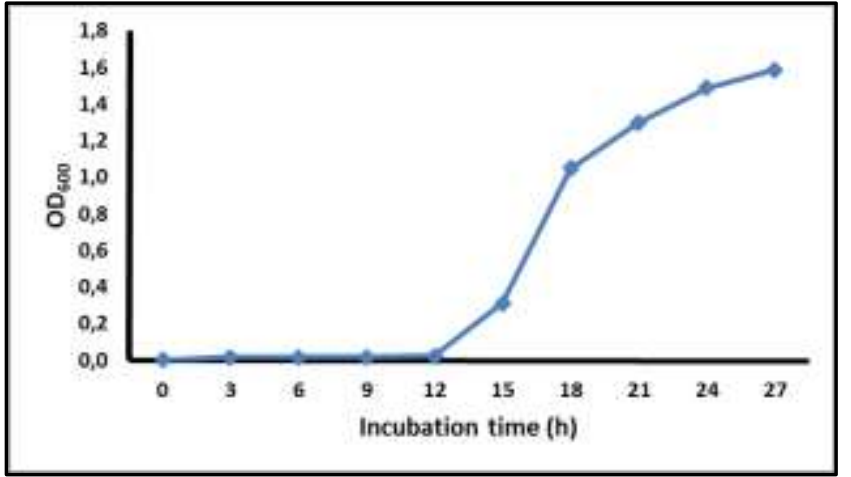

Fig. 4 Growth phase of bacteria B.thuringiensis HCB6

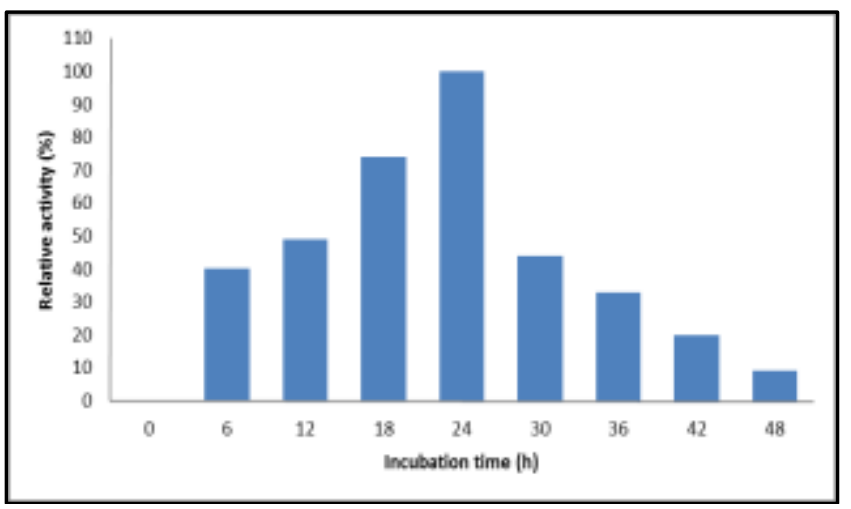

Fig. 5 Crude amylase activity during enzyme production of $B$. thuringiensis HCB6.

in the incubation time of 12 to $18 \mathrm{~h}$ (Fig. 4). The optimal inoculum adaptation time was found to be at 18 hour.

Optimal production time was performed to obtain amylase with the highest activity. The crude amylase activity during enzyme production times was shown in Figure 5. The amylase activity increased at $6 \mathrm{~h}$ to $24 \mathrm{~h}$ of the incubation time, and decreased afterward. The increasing enzyme activity represented the production of amylase by the bacteria while the decrease of enzyme may be caused by catabolic repression of glucose that was released as starch hydrolysis and proteolysis of amylase [18]. The amylase activity may decrease also, the decrease of enzyme production was caused by the cells that reached their stationary phase [19].

The incubation period of $B$. thuringiensis HCB6 was similar to previous study of $B$. licheniformis at 24 hours of incubation time [11]. The B.thuringiensis HCB6 had lower optimal production time than that of amylase of $B$.

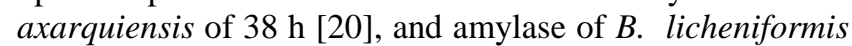
of $48 \mathrm{~h}$ [21]. The optimal inoculum adaptation age of $18 \mathrm{~h}$ and enzyme production of $24 \mathrm{~h}$ were then used to produce the amylase for further study of amylase purification and characterization.

Crude amylase optimum $\mathrm{pH}$ was studied in the range of 2.0 to 7.0 (Fig. 6). Amylase activity was increased along with the $\mathrm{pH}$ from 2.0 to 4.0 and it was decreased after reaching

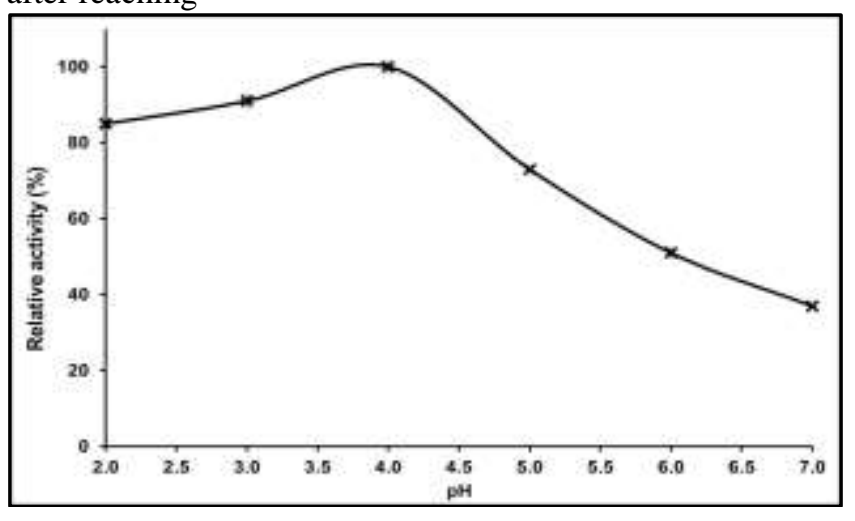

Fig. $6 \mathrm{pH}$ effect to the amylase activity.

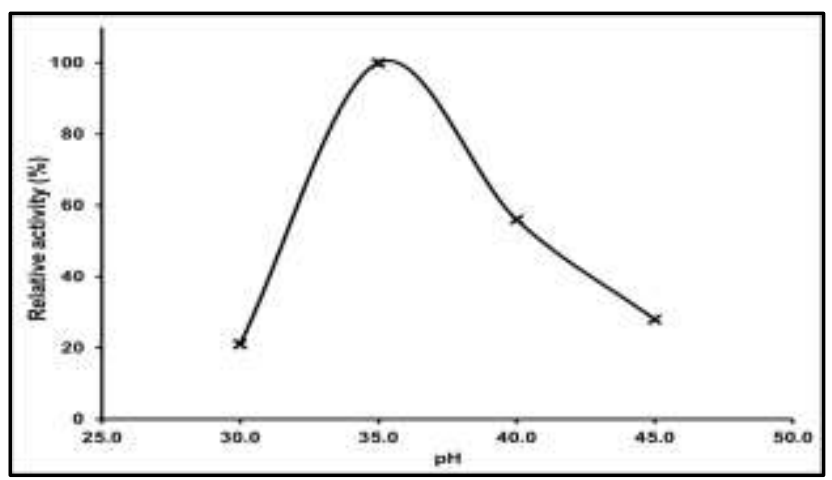

Fig. 7 Temperature effect to the amylase activity

the optimum $\mathrm{pH}$ of 4.0. At the optimum $\mathrm{pH}$, amylase was in the best conformation, which resulted in the maximum substrate binding and catalyzing at the maximum speed to convert the enzymatic reaction product. At the lower and upper of the optimum $\mathrm{pH}$, the change of $\mathrm{pH}$ may change the amino acid side change ionization on the active site of the amylase, resulted in the decreasing the amylase activity.

Enzymatic reaction is similar to general chemistry reaction, in which the reaction rate would increase with the temperature due to the increase of kinetic energy. The increase of this energy would increase the chances of collision between enzyme and substrate, resulted in higher substrate-product catalysis. However, since enzymes were protein, the three-dimensional structure would change easily by increasing temperature, that may destroy some quaternary, tertiary or secondary structure of the enzyme. The changes of these structures would lead to conformation changes of the enzyme active site, which finally decreased the enzymatic product reaction. The crude amylase in this study showed an increasing activity with the temperature from 30 to $35{ }^{\circ} \mathrm{C}$, however, at the higher 
Table $1 B$. thuringiensis HCB6 amylase partial purification by ammonium sulfate precipitation.

\begin{tabular}{cccccc}
\hline Purification Steps & Total Activity $(\mathbf{U})$ & Total Protein $(\mathbf{m g})$ & $\begin{array}{c}\text { Specific activity } \\
(\mathbf{U} / \mathbf{m g})\end{array}$ & Yield (\%) & Purification fold \\
\hline Crude amylase & $5804.94 \pm 0.00$ & $488.03 \pm 0.00$ & $11.90 \pm 0.00$ & 100.00 & 1.0 \\
FHD 20\% & $25.81 \pm 0.60$ & $2.70 \pm 0.01$ & $9.55 \pm 0.19$ & 0.45 & 3.8 \\
FHD 40\% & $33.01 \pm 0.00$ & $0.88 \pm 0.01$ & $37.56 \pm 0.38$ & 0.57 & 0.28 \\
FHD 60\% & $16.08 \pm 0.00$ & $1.61 \pm 0.02$ & $9.99 \pm 0.11$ & & 0.8 \\
\hline
\end{tabular}

temperature, the amylase structure seems changes. It was resulted in the decreasing of the amylase activity (Fig. 7).

Each protein has various solubility in different ionic strength of the solution, and ionic strength depends on the salt concentration. This principle was generally used to separate the specific protein from the mixture. In this study, crude amylase with various protein was purified using ammonium sulfate precipitation. The ammonium sulfate concentrations used were $20 \%, 40 \%$ and $60 \%$, followed by salt removal by dialysis. The amylase activity is shown in Table. 1, where amylase activity and specific activity of every fraction increased with the purification steps. The amylase activity on the salt concentration of $20 \%$ was lower than crude amylase, thus, in this condition, nonamylase proteins were more dominant. The same reason goes for the salt concentration of $60 \%$. The fraction with the highest specific activity was FHD $40 \%$ with specific activity of $37.56 \mathrm{U} \mathrm{mg}^{-1}$ and purification fold of 3.2. The total protein of purified amylase was decreased, due to other protein interferences were separated during purification.

The obtained amylase was the characterized for its molecular weight using SDS PAGE electrophoresis. The result showed crude amylase (Fig. 8 - 1) had several protein bands, whereas the purified amylase (Fig. 8 - 5) showed two bands of $32 \mathrm{kDa}$ and $35 \mathrm{kDa}$. This result showed a good purification of amylase of B. Thuringiensis HCB6, however, this partial purification did not result a pure amylase of one band only. The molecular weight of resulted amylase was similar to amylase of Aspergillusgracilis that is $35 \mathrm{kDa}$ [22]. The proposed amylase molecular weight was also similar to the common

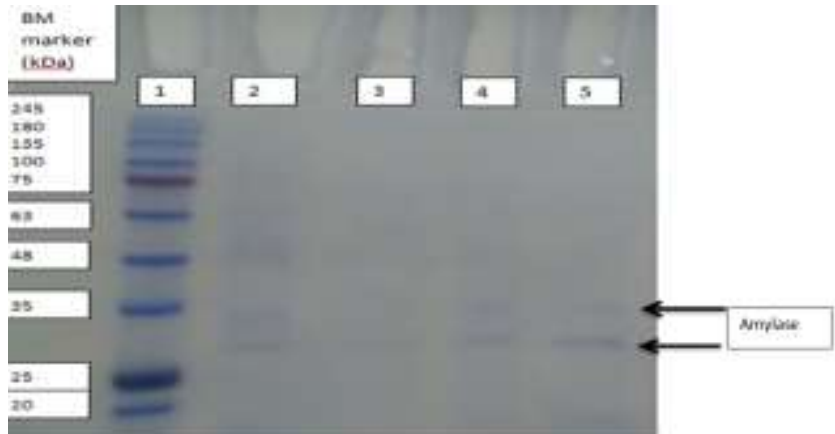

Fig. 8 SDS page profile of protein marker (1) crude amylase (2) freeze-dried crude amylase (3) FHD40\% amylase (4) and freezedried FHD40\% amylase (5).

amylases molecular weight from microorganism, which are normally between $32-68 \mathrm{kDa}$ [23].

\section{CONCLUSION}

Several bacteria were isolated from tapioca liquid waste, with the highest activity for amylase-producing bacteria. was identified as Bacillus thuringiensis. The amylase optimal production is $18 \mathrm{~h}$ of cultivation adaptation period and $24 \mathrm{~h}$ of amylase production. Partial purification of amylase shows the FHD40\% showed highest specific activity of $37.56 \pm 0.38 \mathrm{U} \mathrm{mg}^{-1}$ with the purification fold of 3.2. The SDS-PAGE profile shows two bands of amylase with the molecular weight of $32 \mathrm{kDa}$ and $35 \mathrm{kDa}$, respectively.

\section{ACKNOWLEDGEMENTS}

This research is supported by The Directorate General of Higher Education through the Fundamental research number DIPA-023.04.1.673453/2015. 


\section{REFERENCES}

[1] M.J. Van Der Maarel, B. Van Der Veen, J.C. Uitdehaag, H. Leemhuis, L. Dijkhuizen, Journal of biotechnology, 94(2002) 137-55

[2] K. Kathiresan, S. Manivannan, African journal of Biotechnology, 5(2006).

[3] S. Elayaraja, T. Velvizhi, V. Maharani, P. Mayavu, S. Vijayalakshmi, T. Balasubramanian, African Journal of Biotechnology, 10(2013) 11235-8.

[4] A. Fatoni, Songklanakarin Journal of Science and Technology, 34(2012) 525-31

[5] Zusfahari, Puji Lestari, D.R. Ningsih, Inovasi, 4(2010).

[6] T. Setyaningtyas, A. Fatoni, Jurnal Natur Indonesia, 12(2012).

[7] E. Mobarak-Qamsari, R. Kasra-Kermanshahi, Z. Moosavi-Nejad, Iranian journal of microbiology, 3(2011) 92.

[8] A. Fatoni, P. Lestari, Jurnal Natur Indonesia, 10(2012).

[9] S. Sneha, M.P. Das, L.J. Rebecca, Journal of Chemical \& Pharmaceutical Research, 6(2014)

[10] A. Samanta, D. Mitra, S.N. Roy, C. Sinha, P. Pal, Journal of Environmental Protection, 4(2013) 647-52.

[11] S. Vaseekaran, S. Balakumar, V. Arasaratnam, Tropical Agricultural Research, 22(2010) 1-11.

[12] Zusfahair, D.R. Ningsih, D. Kartika, 1st Pharmacy International Conference, Universitas Muhammadiyah Purwokerto, Purwokerto, Indonesia, 2015.
[13] N. Nelson, J biol Chem, 153(1944) 375-80.

[14] D. Pitcher, N. Saunders, R. Owen, Letters in Applied Microbiology, 8(1989) 151-6.

[15] A. Hiraishi, K. Muramatsu, Y. Ueda, Systematic and applied microbiology, 19(1996) 168-77.

[16] O.H. Lowry, N.J. Rosebrough, A.L. Farr, R.J. Randall, J biol Chem, 193(1951) 265-75.

[17] S. Alrumman, Y. Mostafa, S. Eifan, S. Alamri, A. Hesham, Adv Life Sci Technol, 20(2014) 41-51.

[18] P. Gautam, A. Sabu, A. Pandey, G. Szakacs, C.R. Soccol, Bioresource technology, 83(2002) 229-33.

[19] V. Mulimani, G. Patil, Biochemical education, 28(2000) 161-3.

[20] S.A. Alrumman, Y.S. Mostafa, S.A. Eifan, S.A. Alamri, A.E.-L. Hesham, Advances in Life Science and Technology, 20(2014) 4151.

[21] M. Fahimeh, N. Bahador, M. Baserisalehi, Afr J Microb Res, 7(2013) 4483-90.

[22] I. Ali, A. Akbar, B. Yanwisetpakdee, S. Prasongsuk, P. Lotrakul, H. Punnapayak, BioMed research international, 2014(2014).

[23] D. Nangin, A. Sutrisno, Jurnal Pangan dan Agroindustri, 3(2014). 